\title{
An Analysis of High-Rise Building Fires and Human Firesafety Consciousness through Fire Statistics and Field Survey
}

\author{
ROSARIA ONO \\ Fire Safety Laboratory \\ Technological Research Institute of São Paulo State - IPT \\ P.O. Box 0141, Postal Code 01064-970, São Paulo, SP, BRAZIL
}

\begin{abstract}
As one of the main megacities in developing countries, São Paulo is characterized by serious urban problems found in undeveloped countries and some amenities from developed ones. One of the consequences of this situation is the unique firesafety problems found in large scale buildings such as shopping malls, multiple-use complexes and high-rise buildings, where the lack of adequate fire regulation can drive to the construction of "modern" but unsafe spaces.

This paper presents the results of a study of high-rise building fires through the analysis of the São Paulo State Fire Department database as well as the results of a field survey in high-rise office buildings, focusing the matter of the occupant's firesafety consciousness. Despite the concern of some public authorities about firesafety improvement, it is very clear that the general population and particularly those who live or work in high-rise buildings are neither aware of fire prevention measures nor prepared to face fire incidents. These matters are also discussed and analyzed in this paper.
\end{abstract}

KEY WORDS: Fire statistics, high-rise building fires, field survey, fire safety consciousness.

\section{INTRODUCTION}

The City of São Paulo in Brazil presents several urban problems that are typical of megacities and, among those, firesafety in high-rise buildings is focused on here. The São Paulo's first high-rise office building, built in 1934 (the Martinelli Building - 32 floors), turned to be the landmark of the introduction of reinforced concrete structure in Brazil. From that time, all high-rise structures were built without much concern about firesafety until the first two tragedies occurred in São Paulo: the Andraus Building fire (in 1972 - 16 deaths) and Joelma Building fire (in 1974 - 180 deaths). Among the several high-rise building fires that followed those mentioned above, the significant ones are listed in Table 1. Further information about some of those fires was presented previously [1].

As a consequence of those fires, regulations on firesafety have been reinforced in major cities of Brazil, however, the evaluation of its implementation has not been carried out. On the other hand, the population in general gets shocked at each tragic incident, but the impact is temporary to most people and it rarely raises the awareness to firesafety problems in their daily lives.

In this paper an evaluation of the level of implementation of existing fire regulations in high-rise buildings is intended, together with the evaluation of firesafety consciousness of 
the population through the analysis of fire incident reports and a field survey in existing buildings.

Table 1. The significant high-rise building fires in São Paulo

\begin{tabular}{cccccc}
\hline Date & Building & Type of Occupancy & Deaths & $\begin{array}{c}\text { Floor of } \\
\text { origin }\end{array}$ & $\begin{array}{c}\text { Damaged Floors (Total } \\
\text { number of floors) }\end{array}$ \\
\hline 1976.19.11. & Banco Real & under construction & 0 & $12^{\text {th }}$ & $12^{\text {th }}(16)$ \\
1978.04 .09$. & Nacional & Office & 0 & $1^{\text {st }}$ & $1^{\text {st }}$ to $9^{\text {th }}(26)$ \\
1980.09 .04$. & Sec. Fazenda & Office & 0 & $13^{\text {th }}$ & $13^{\text {th }}$ to $14^{\text {th }}(22)$ \\
1981.14 .02$. & Grande Avenida & Office & 17 & $1^{\text {st }}$ & $1^{\text {st }}$ to $19^{\text {th }}(23)$ \\
1983.03 .06$. & Scarpa & Office & 0 & $12^{\text {th }}$ & $12^{\text {th }}$ to $13^{\text {th }}(17)$ \\
1987.21 .05$. & CESP Tower I & Office & 2 & $5^{\text {th }}$ & $5^{\text {th }}$ to $21^{\text {st }}(21)$ \\
& CESP Tower II & Offe & --- & structural collapse $(27)$ \\
\hline
\end{tabular}

\section{THE FIRE DATABASE}

Firstly, a fire statistics analysis was performed using the database provided by the Fire Department of São Paulo State for the 1994 to 2000 period. The review of the fire data collection system in 1993 allowed the analysis of high-rise building fires in this study.

The number of stories that defined high-rise buildings here ( 8 stories or higher) was based on the São Paulo State Fire Protection Regulation, which establishes as high-rise buildings higher than 23 meters, considering the distance between the level of discharge and the highest occupied floor. Table 2 presents general numbers of structure fires and high-rise building fires in the City of São Paulo.

\section{Table 2 - Total of fire incidents in the City of São Paulo (1994-2000)}

\begin{tabular}{lccccccc}
\hline Type of fire & 1994 & 1995 & 1996 & 1997 & 1998 & 1999 & 2000 \\
\hline Structure & 3,545 & 3,491 & 3,353 & 3,351 & 3,634 & 4,181 & 4,040 \\
High-rise buildings & 141 & 203 & 111 & 99 & 69 & 58 & 59 \\
\hline
\end{tabular}

Despite the increasing number of structure fires in the City of São Paulo in the last three years, it is possible to see that the number of fires in high-rise buildings has decreased since 1996. The reason of this decrease can not be determined only by the fire data analysis; however, the likely reason is the reinforcement of new, stricter State fire regulations since 1993, both for new and existing buildings. It can also be seen that the proportion of high-rise building fires in the total number of structure fires is very small (average of $3.0 \%$ ). However, the major concerns in this case are the severity and the consequences of high-rise building fires.

At first, the data was plotted by month, as demonstrated in Fig.1, in the attempt to identify any trend in fire incidents in high-rise buildings, as well as to verify the feasibility of a comprehensive analysis by summing up several years' data. By the analysis of this figure, a major difference was primarily noted in the monthly distribution of fire incidents of 1994 and 1995, compared to the following years. An analysis of variance (ANOVA) confirmed such difference.

Next, a statistical evaluation by cluster, using the " $\mathrm{k}$ means" method was carried out to 
group them into two sets of data. Cluster 1 includes data from 1994 and 1995, and Cluster 2, from 1996 to 2000. Based on this result, the analysis was restricted to the data base of 1996 to 2000 period, as they represent the most recent set of data.

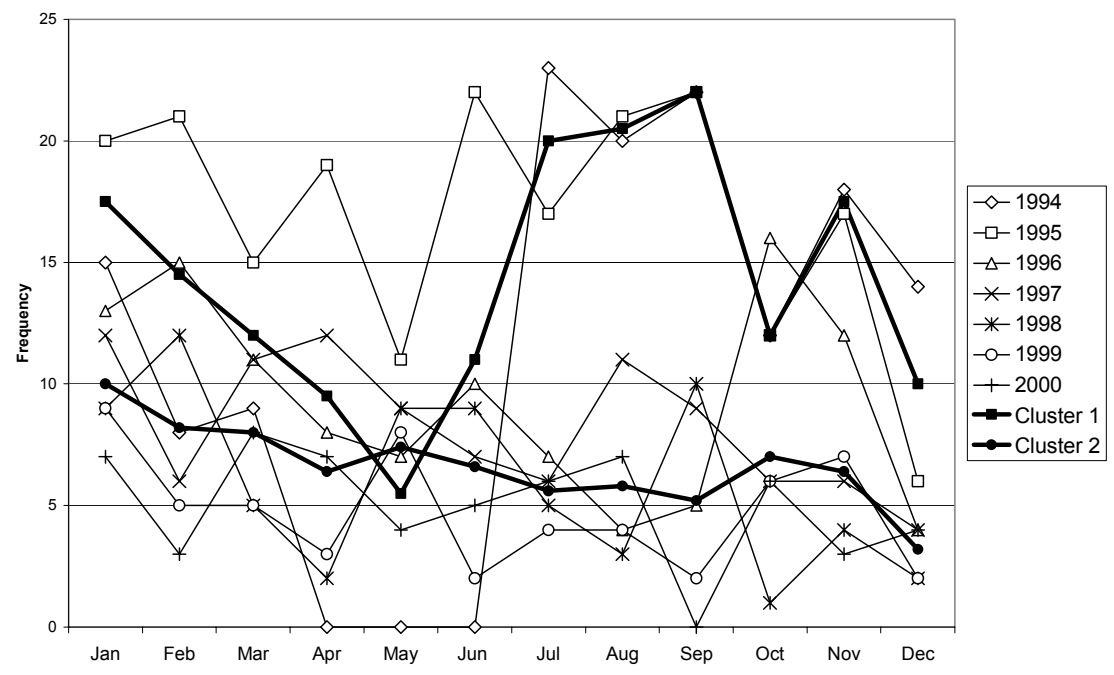

Figure 1 - High-rise building fires in the City of São Paulo by month (1994-2000)

\section{THE HIGH-RISE BUILDING FIRES IN THE CITY OF SÃO PAULO}

The total number of fire cases in high-rise buildings during the 1996-2000 period is shown in Table 3, by type of occupancy.

Table 3 - High-rise building fires by type of occupancy (1996-2000)

\begin{tabular}{llllll}
\hline & 1996 & 1997 & 1998 & 1999 & 2000 \\
\hline Residential & $91(82 \%)$ & $78(79 \%)$ & $51(74 \%)$ & $46(79 \%)$ & $55(93 \%)$ \\
Commercial & $3(3 \%)$ & $3(3 \%)$ & $2(3 \%)$ & $2(3 \%)$ & $0(0 \%)$ \\
Offices & $7(6 \%)$ & $13(13 \%)$ & $9(13 \%)$ & $5(9 \%)$ & $4(7 \%)$ \\
Health care & $2(2 \%)$ & $1(1 \%)$ & $1(1 \%)$ & $0(0 \%)$ & $0(0 \%)$ \\
Other & $8(7 \%)$ & $4(4 \%)$ & $6(9 \%)$ & $5(9 \%)$ & $0(0 \%)$ \\
\hline Total & $111(100 \%)$ & $99(100 \%)$ & $69(100 \%)$ & $58(100 \%)$ & $59(100 \%)$ \\
\hline
\end{tabular}

In the classification shown above, "Residential" also includes hotels; "Commercial" means places where "buy\&sell" activities are developed, including restaurants and bars; private and public offices are included in "Offices"; "Health care" includes hospitals and clinics; and construction sites, industrial and entertainment buildings are located in "Other".

Residential fires represent the highest fire rate in high-rise buildings in the City of São Paulo (average of $81 \%$ in the last 5 years), higher than the rate of all residential fires in all structure fires (average of 58\%, according to a study presented previously[2]). This type of occupancy is followed, far beyond, by office buildings, which presents an average of $10 \%$ of all high-rise fires. The distribution of high-rise buildings fires according to the height of the building is shown in Fig.2. Figure 3 shows the distribution by floor of fire origin. 


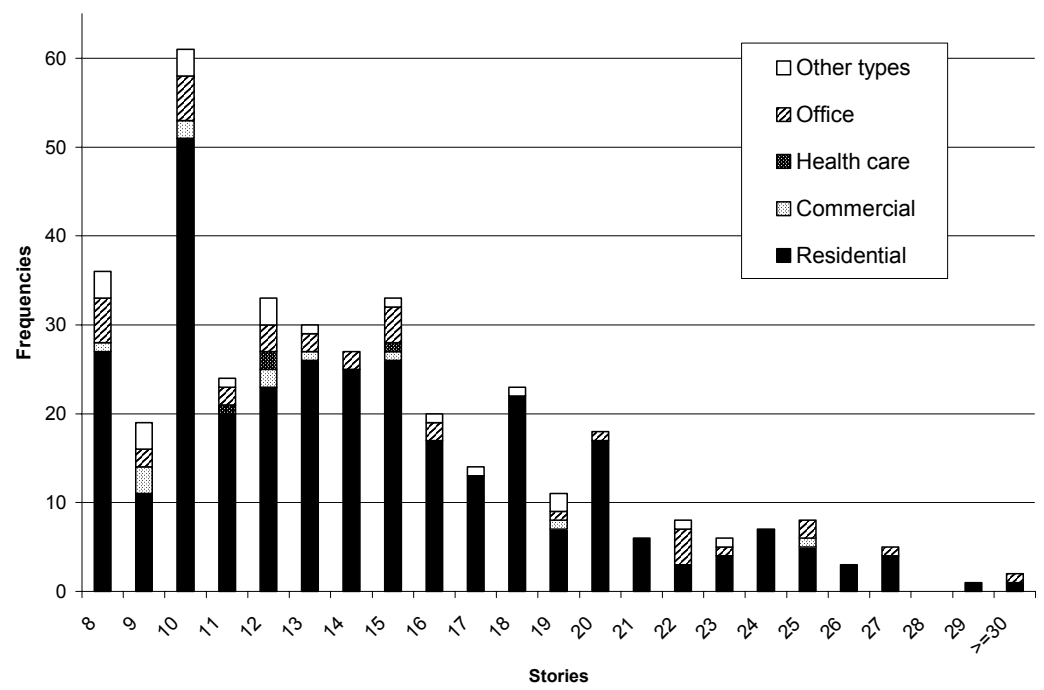

Figure 2 - High-rise building fires by building height

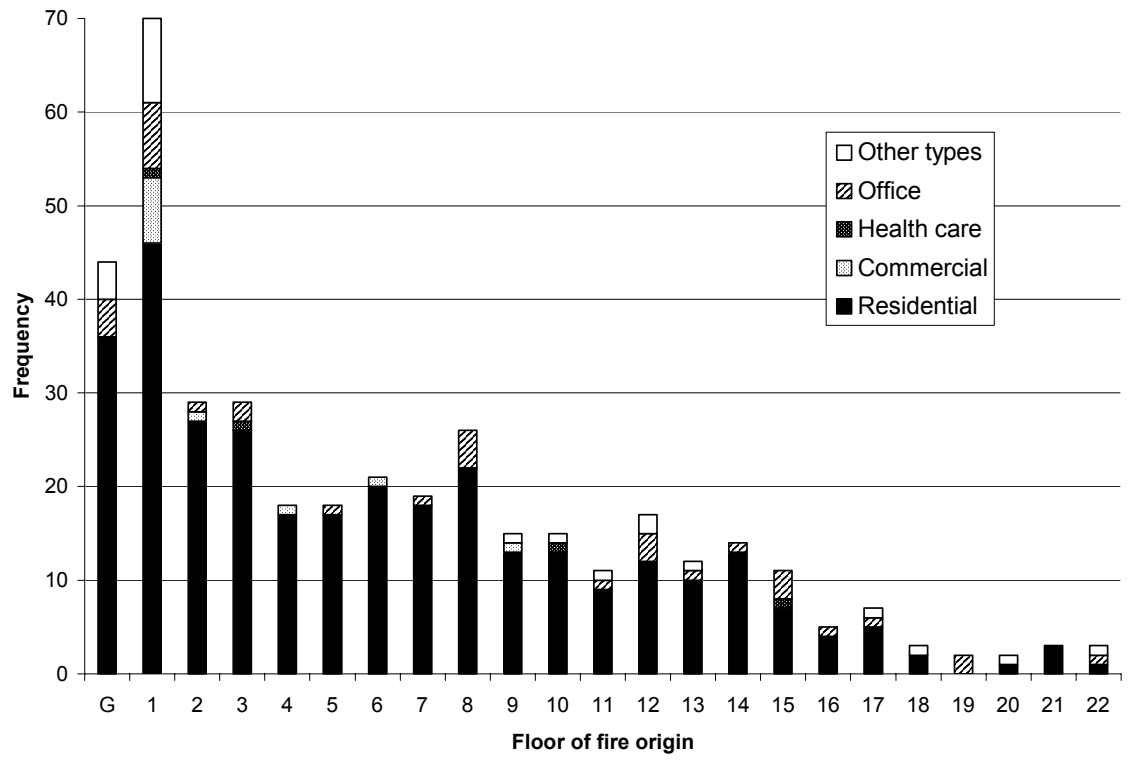

Figure 3 - High-rise building by floor of fire origin

The concentration of fires in buildings between 8 to 20 stories can be seen in Fig.2, which are, together, responsible for approximately $89 \%$ of the total occurrences. Since there are no official figures about the existing high-rise buildings in São Paulo, it is not possible to compare fire incidents and their proportion to the total number of this type of building. The only estimated figure is the number of building higher than 4 stories, that are probably between 30,000 to 35,000 in the city. 
On the other hand, Fig. 3 shows that there is a significant frequency of cases where the floor of fire origin is located on the $8^{\text {th }}$ floor or below ( $70 \%$ of all cases). Additionally, by the concentration of fires at the ground floor or one floor above in different types of occupancy, it can be said that in some of the fire cases the occupancy indicated at the database is the one at the fire floor (lower floors), that probably was different from the upper floors of the building. This is a typical situation of buildings where the two lower floors are used for commercial purposes (restaurants, bars, small shops) and the above floors are, in most cases, for residential or office purposes. The database does not allow the distinction between the specific occupancy of the place of fire origin and the primary (main) occupancy of the building.

It is also possible to see that there is no case of fire initiated in stories higher than the $22^{\text {nd }}$ in Fig. 3, which can mean, if associated to Fig. 2, that the number of such kind of buildings in the city is still small. Further analysis is required to understand the consequences of those fire incidents, mainly related to the extension of its damage. Table 4 presents the number of cases where the fire was limited or not to the floor of origin and Fig. 4, its damaged floor area.

Table 4 - High-rise building fires by the fire containment (1996-2000)

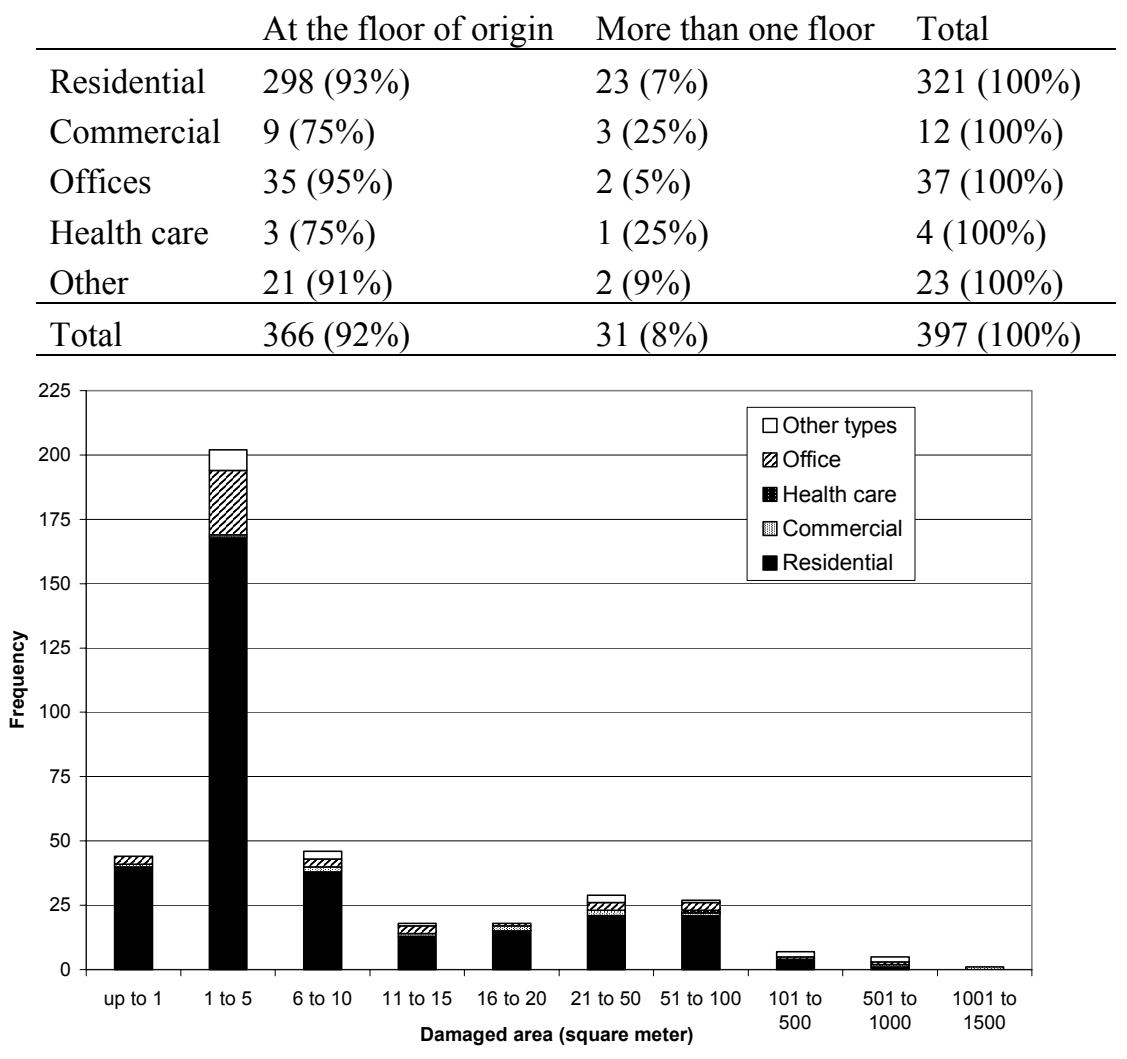

Figure 4 - Damaged floor area by type of occupancy

According to Table 4 and Fig.4, respectively, only $8 \%$ of all fires were not limited to the floor of origin, and $62 \%$ of the damaged area was equal to or lower than $5 \mathrm{~m}^{2}$. This phenomenon can be justified by the building materials and systems traditionally adopted 
in Brazil, which have resulted in highly compartmented spaces.

\section{FIRE SAFETY IN HIGH-RISE BUILDINGS OTHER THAN RESIDENTIAL}

As it could be seen from the data presented here, most of the fire cases in high-rise buildings, as well as in all structure fires, is concentrated on residential buildings. Comparing the results of this analysis to what was presented previously [2], it is possible to say that residential building fires in high-rise or low-rise buildings present, essentially, very similar fire causes, behavior and consequences, such as few casualties, low propagation and reduced damaged area.

Due to this situation and the severe fires in high-rise office buildings that the City of São Paulo has faced, further analysis were conducted on occupancies other than residential in high-rise buildings. The results of this analysis were also useful for the comparison with the results of the field survey that was conducted in office buildings [3] that will also be presented in this paper.

Among the additional information about the buildings in the São Paulo Fire Department fire database, the existing fire protection systems and their use can be found. However, it can be concluded that an improvement is necessary to increase the reliability of this data, that shows no fire protection system installed in $61 \%$ of the 76 cases of non-residential high-rise building fires. Such information probably has not been completely filled up in all fire cases. Despite this situation, some conclusion could be drawn from the data that was effectively filled up ( $39 \%$ of those cases $=30$ cases $)$, as shown in Table 5 .

\section{Table 5. The existing fire protection systems (active) in 30 buildings}

\begin{tabular}{lccccc}
\hline Type of occupancy & $\begin{array}{c}\text { Fire } \\
\text { Extinguishers }\end{array}$ & $\begin{array}{c}\text { Emergency } \\
\text { Lights }\end{array}$ & Fire Alarms & Hydrants & Sprinklers \\
\hline Commercial & 5 & 2 & 3 & 4 & 0 \\
Offices & 16 & 13 & 11 & 15 & 3 \\
Health care & 3 & 1 & 2 & 3 & 0 \\
Other & 4 & 1 & 1 & 3 & 0 \\
\hline Total Installed & $28(93 \%)$ & $17(57 \%)$ & $17(57 \%)$ & $25(83 \%)$ & $3(10 \%)$ \\
\hline
\end{tabular}

Another data that must be interpreted cautiously is the effectiveness of those existing active fire protection systems. According to the fire database, only one type of protection system installed in the building (fire extinguishers) was effective in two fire cases. Additionally, only 5 buildings had their own firesafety team (generally composed by security personnel) properly instructed as required and only one of them worked properly at the moment of fire. The fire regulations in the City of São Paulo require fire extinguishers, emergency lights, fire alarms, fire hydrants for buildings above $12 \mathrm{~m}$ and sprinklers systems for buildings above 30m (except residential) since 1983.

The results of a survey carried out by the author [3] are able to complement some of the data presented above. This survey was the main activity of a Research Project supported by the Department of Science, Technology and Economical Development (SCTDE) of São Paulo State Government, whose objective was to develop a comprehensive study on firesafety conditions of high-rise office buildings in the city of São Paulo, as well as on their occupants' firesafety consciousness and preparedness for fire.

In this study, 41 high-rise office buildings were inspected, building managers were interviewed and occupants filled up a questionnaire about their firesafety preparedness. 
Figure 5 shows the percentage of fire protection systems installed in the inspected buildings. It can be concluded that most of the systems required by regulations (fire extinguishers, fire hydrants, fire alarms, emergency light and fire safety signs) were found in a very high rate, despite the low percentage showed by the Fire Department's database (Table 5).

Only $10 \%$ of those 41 buildings were lower than 10 stories, $51 \%$ were 10 to 15 stories high, 24\% were between 16 and 20 stories high and $15 \%$ were above 20 and under or equal to 31 stories high, so that sprinkler systems would be required in most of the cases.

The low frequency of sprinkler systems, as well as fire stairs (protected by compartmentation) can be justified essentially by the building distribution by age. Amongst the 41 buildings, $47 \%$ were built previous to the 1975 Municipal Building Code, when a significant number of fire safety requirements was firstly introduced. No fire stairs or sprinkler systems were required in high-rise buildings previous to 1975 .

The presence of automatic fire detection systems is quite remarkable in Fig.5, despite the fact that this system is not particularly required in high-rise office buildings, but it is justified by the acceptance of this systems in place of the sprinkler system in existing high-rise buildings where retrofit was needed. Then, adding the number of buildings where automatic fire detection systems and sprinkler systems were found, the rate of installation of one of these systems raises to a considerable percentage of $91 \%$.

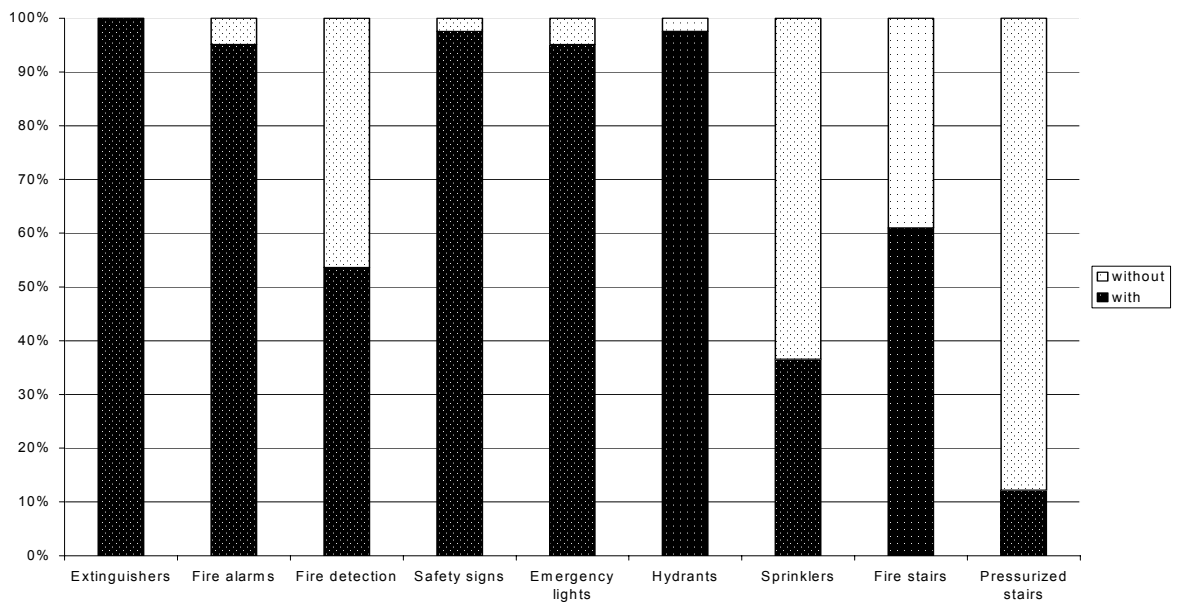

Figure 5 - Frequency of installation of fire protection systems

Apart from the presence of fire protection systems, during the inspections the maintenance conditions of those systems were also verified. Simple systems such as portable fire extinguishers and fire hydrants were found adequate in most of the cases $(90 \%$ and $85 \%$ on average, respectively) considering aspects such as accessibility, distribution and appearance. However, other types of systems such as manual fire alarms, automatic fire detection and alarm, sprinkler systems and fire exit signs presented several problems related to design and maintenance. It was confirmed by interviewing building managers that most of the inspected buildings do not carry out maintenance of fire protection systems or keep records, except for extinguishers and hydrants, which are easily checked 
by the building manager and his staff. There is also a general lack of consciousness and knowledge about the basic procedures for adequate maintenance of those systems.

Some aspects of passive fire protection systems were also verified, such as the fire stairs, compartmentation of open spaces such as vertical shafts and other types of fire barriers. The most alarming problem was found in the vertical shafts, as only in $56 \%$ of all cases the compartmentation was adequate. In most of the old buildings, a retrofit had not been carried out and in some recent buildings, the compartmentation had been partially or totally removed to renew the cabling system and never rebuilt. The comparison of this information with the fire database has not been possible since today the Fire Department does not keep records about the means of fire, heat and smoke propagation in building fires.

However, the complementation of some other data has been possible, such as the fire problems caused by electricity. Among the fire causes recorded by the Fire Department database in high-rise buildings (except residential buildings), electrical problems such as short circuit and overheat of electrical appliances represented $30 \%$ of all fire incidents. As a result of the inspections carried by the author, $27 \%$ of the buildings presented problems on the electrical distribution board and 32\% in the wiring (overheat, lack of isolation, overloaded wiring, etc.), found mainly in buildings where the electrical load had not been reviewed as a result of an increasing electrical consumption in the last decades.

Carelessness at cooking and smoking were pointed out as $8 \%$ and $7 \%$, respectively, of the fire causes in the Fire Department database. The inspection showed the presence of gas for cooking purpose in some kitchens of office buildings, mainly in the janitor's room, however, those were more frequent in old buildings and a clear tendency towards banning gas installation from office buildings was found.

Smoking in workplaces was also observed. The problem detected during the inspections was the lack of a smoking area in most of the buildings leading smokers to fire stairs, where ashtrays were found. Added to this aspect is the illegal placement of garbage cans and bags inside fire stairs in 34\% of the inspected buildings, resulting in a dangerous combination of heat source and combustible material at the same place. The maintenance of fire exits (stairs and corridors) were also inspected and several problems were found, such as temporary and permanent obstruction of access to fire stairs and combustible materials and other objects (furniture, large vases of plants, carpets, dustbins, etc.) along the corridors.

The accessibility of fire engines to the building was another aspect that was surveyed. The Fire Department fire database does not allow this analysis today. Among the inspected buildings, 56\% had only one façade facing an accessible street, 34\% allowed access from two façades and only $10 \%$ presented three free access façades.

\section{FIRESAFETY CONSCIOUSNESS AND PREPAREDNESS}

Some aspects of firesafety consciousness and preparedness of building managers and occupants were considered and surveyed as a continuity to the study developed in Japan [4]. The understanding of the profile of building managers and their staff was one of the objectives of the Research Project, since there is no recognized qualification required for this personnel in Brazil today. By law, any building owned by a group of persons should name a "trustee", who is normally a person who owns part of the building and is legally responsible for the building administration, including firesafety. This person can hire a professional (building manager) or a building administration firm to manage the building, or do it by himself. 
The interview of persons responsible for the firesafety included, essentially, subjects related to the management of fire protection systems and potential fire risks in the building and it was prepared to be carried out with the "trustees", but in some cases only the building manager or the janitor was available. Then 22 "trustees", 7 building managers and 4 janitors were interviewed and their profile is shown on Tables 6 and 7.

Table 6. Interviewed building staff by age

\begin{tabular}{lccccccccc}
\hline \multirow{2}{*}{ Function } & \multicolumn{10}{c}{ Age (years) } \\
\cline { 2 - 11 } & 26 to 30 & 31 to 35 & 36 to 40 & 41 to 45 & 46 to 50 & 51 to 55 & 56 to 60 & +60 & Total \\
\hline Trustee & 1 & 3 & 1 & 3 & 2 & 4 & 4 & 4 & 22 \\
Manager & 0 & 0 & 0 & 1 & 3 & 1 & 0 & 2 & 7 \\
Janitor & 0 & 0 & 0 & 3 & 0 & 0 & 1 & 0 & 4 \\
\hline Total & 1 & 3 & 1 & 7 & 5 & 5 & 5 & 6 & 33 \\
\hline
\end{tabular}

Concerning firesafety training of these people, $20 \%$ declared that they never experienced it, $11 \%$ had been trained once in the last 5 years and $60 \%$ had had some training in the last 12 month period. Among the 7 persons who had never been submitted to training, 6 were "trustees" and 1 was a building manager, which results in $27 \%$ of the 22 trustees without any kind of firesafety training. When this information was crossed with the situation of firesafety teams in the buildings, it was concluded that in 6 out of the 7 buildings where trustees were never trained, there were no firesafety teams, as required by federal labors' safety regulation.

Table 7. Interviewed building staff by formal education

\begin{tabular}{lcccccc}
\hline & $\begin{array}{l}\text { Elementary } \\
\text { (incomplete) }\end{array}$ & $\begin{array}{l}\text { Elementary } \\
\text { (complete) }\end{array}$ & $\begin{array}{l}\text { High-School } \\
\text { (incomplete) }\end{array}$ & $\begin{array}{l}\text { High-School } \\
\text { (complete) }\end{array}$ & $\begin{array}{l}\text { College } \\
\text { (incomplete) }\end{array}$ & $\begin{array}{l}\text { College } \\
\text { (complete) }\end{array}$ \\
\hline Trustee & 0 & 0 & 0 & 5 & 0 & 17 \\
Manager & 0 & 0 & 0 & 3 & 2 & 2 \\
Janitor & 1 & 2 & 0 & 0 & 0 & 1 \\
\hline Total & 1 & 2 & 0 & 8 & 2 & 20 \\
\hline
\end{tabular}

When asked about the maintenance records of fire protection systems, $60 \%$ answered they kept records, however, during the inspections lower percentages of records were found: $49 \%$ of fire hydrants and hoses; $40 \%$ of the sprinkler systems; and $10 \%$ of the manual alarm systems.

Concerning corrective or preventive maintenance, $37 \%$ declared that generally they look for "quality and reasonable prices" when hiring services, but only few of them had technical criteria for the acceptance of those services and $26 \%$ has no criteria at all. The result of this attitude could be seen during the inspection of those systems, where inadequate design and maintenance conditions of fire protection systems were found.

The source of firesafety information and orientation was asked and $77 \%$ declared several different sources such as building administration firms, Fire Department, specialized fire protection firms, etc., but it is worrisome that $23 \%$ declared they did not have any kind of supporting source of information or orientation concerning firesafety maintenance of their buildings.

Another aspect that was considered in the interviews was the firesafety consciousness of building managers and trustees. $77 \%$ of them answered they felt the installed fire 
protection systems were enough to guarantee the building safety from fire. About the potential risk of fire in their building, $63 \%$ declared there was no potential, $18 \%$ pointed out electrical problems, $8 \%$ pointed out smoking problems, $3 \%$ of gas leak and another $3 \%$, vandalism. Based on the results of the interviews, it was concluded that, in general, there is an alarming lack of qualified personnel in building management, when firesafety is the concern.

About 200 questionnaires were distributed amongst the building occupants in order to obtain some information about their firesafety consciousness and preparedness for fire incidents. $80(40 \%)$ of them were answered. Considering their age and gender, the distribution is shown on Table 8, and by formal education, on Table 9.

\section{Table 8. The distribution of building occupants by age}

\begin{tabular}{lcccccccc}
\hline & Up to 25 & 26 to 35 & 36 to 45 & 46 to 55 & +55 & Not declared & Total \\
\hline Female & 6 & 9 & 11 & 4 & 1 & 5 & 36 \\
Male & 8 & 9 & 6 & 11 & 8 & 2 & 44 \\
\hline Total & 14 & 18 & 17 & 15 & 9 & 7 & 80 \\
\hline
\end{tabular}

Table 9. The distribution of building occupants by formal education

\begin{tabular}{lcccccc}
\hline & $\begin{array}{l}\text { Elementary } \\
\text { (incomplete) }\end{array}$ & $\begin{array}{l}\text { Elementary } \\
\text { (complete) }\end{array}$ & $\begin{array}{l}\text { High-School } \\
\text { (incomplete) }\end{array}$ & $\begin{array}{l}\text { High-School } \\
\text { (complete) }\end{array}$ & $\begin{array}{l}\text { College } \\
\text { (incomplete) }\end{array}$ & $\begin{array}{l}\text { College } \\
\text { (complete) }\end{array}$ \\
\hline Female & 1 & 0 & 1 & 10 & 7 & 17 \\
Male & 4 & 1 & 2 & 10 & 6 & 21 \\
\hline Total & 5 & 1 & 3 & 20 & 13 & 38 \\
\hline
\end{tabular}

When asked about experience of firesafety training, 59\% answered never having experienced such a training and only $16 \%$ had had a training in the last twelve months. Among those that were submitted to training in the last year, 53\% declared they had taken a session in a compulsory basis. The occupants were also asked about the first attitude to be taken in case of a fire alarm and the answer was distributed as represented in Table 10.

Table 10. First attitude to be taken in case of fire

\begin{tabular}{ccccc}
\hline Go down stairs & Confirm the fire & Warn other people & Not Declared & Other \\
\hline $43 \%$ & $35 \%$ & $13 \%$ & $6 \%$ & $5 \%$ \\
\hline
\end{tabular}

The experience of fire drills was also asked and $75 \%$ answered they had never participated in fire drills, however, $91 \%$ of them declared to be very familiar with the fire exits and $74 \%$ felt safe in their building.

When asked about experience and knowledge of the operation of fire protection systems, $65 \%$ declared to be able to activate a manual fire alarm, only $40 \%$ to handle a fire extinguisher and $47 \%$ would be able to use fire hoses. These percentages also reflected the low rate of firesafety training of those occupants. The number of people that declared to be unable to activate the manual fire alarm is very worrisome since this operation requires no special training or skill and it is essential for the rapid warning of a possible fire.

A question about the contribution of occupants to the fire prevention in their buildings was asked. Only $28 \%$ of those occupants thought / felt they could contribute to the fire safety. 
A non-parametric interdependency test based on Chi-square was carried out with some of the data concerning the occupants' answers in order to evaluate the fit of data (frequencies) to any arbitrary set of expected frequencies. This procedure allows to enter 2 variables, one containing the expected and another containing the observed frequencies. The expected frequencies adopted in the tests, which aimed at analyzing the relation between certain parameters related to age, gender and formal education, was the equal distribution along those parameters.

It was possible to conclude that the knowledge of fire exits and the feeling of safety in the building were not directly related to age, gender or formal education of building occupants. On the other hand, the older and further educated were more confident to use fire extinguishers and fire hydrants as well as to activate manual fire alarms. The ability to use fire extinguishers, particularly, did not differ between male and female; however, it can be said that the male population felt more able to use manual fire alarms and fire hydrants than the female population did.

The result of comparison between the answers to the question "What are the fire protection systems installed in this building?" and the effectively installed ones, verified in the field inspections, demonstrated that only $26 \%$ answered correctly. If the number of occupants that missed 1 type of installation is added, $50 \%$ of the occupants answered correctly or close to it.

The highest rate of correct answers was found concerning fire extinguishers. Only one person did not point out the existence of this equipment when it existed. Then, $26 \%$ of occupants of buildings where fire sprinkler systems are installed did not point it out. So did it happen with the percentage of 35\% for the fire hydrants, 39\% for the emergency lights, $40 \%$ for the automatic fire detection system and $42 \%$ for the manual fire alarm system.

From this analysis, the hypothesis that a considerable percentage of the building occupants are not familiar with fire protection systems can be raised as a major problem.

\section{CONCLUSIONS}

Several conclusions and discussions were presented along the paper, however, some are emphasized here in order to contribute to future research in the field of study of firesafety.

- In developing countries a lack of basic official numbers is still a very common fact. Although the development of reliable sources of information, such as the fire data base and a database about the buildings and their maintenance conditions are essential for the analysis of fire risks, the databases, they are still very rare and poor. On the other hand, compatibility among data bases is also a very important issue to be considered in order to make comparative analysis possible;

- Professional qualification is needed not only for the design and installation of fire protection systems in buildings but also for carrying out the maintenance of those systems. It was possible to see that there is a serious problem concerning firesafety management in buildings. Considering the very few buildings where the survey was allowed, which means, where the "Trustee" supposed the building was in good firesafety conditions, the situation is very worrisome;

- The lack of knowledge and preparedness of building occupants to face fire incidents is also a very serious concern. The low numbers presented here can also influence the maintenance conditions of fire protection systems in buildings; 
- Although further improvements are needed in certain aspects, it is possible to say that the fire safety requirements have been regularly implemented in the high-rise buildings in the last two decades. However, the vulnerability of old buildings to fire, even after retrofitting, was visible during the inspections, as several problems related to the lack of a global firesafety system were detected.

- An important issue to be considered at the same level of importance of the implementation of fire safety requirements based on fire regulations is the consolidation of a consistent planning to guarantee the maintenance of those fire protection systems, once they have been built or installed. The inspections revealed several problems of maintenance of fire protections systems that can lead to their ineffectiveness along the building life, if adequate maintenance procedures are not carried out.

\section{ACKNOWLEDGEMENTS}

This work had the support of the Fire Department of the Military Police of São Paulo State, that gently allowed access to the fire incident database. The study and development of fire statistics and their analysis is also a project supported by the Technological Research Institute of São Paulo State (IPT) and the State of São Paulo Research Foundation (FAPESP).

\section{REFERENCES}

[1] Berto, A.F. Aprendendo com grandes incêndios em edifícios altos (Learning from high-rise building fires in São Paulo) in NFPA America's Fire Expo Presentation Booklet, Session T3.2, National Fire Protection Association, Miami, July 24-25, 2001 (in Portuguese).

[2] Ono, R., Silva, S. B. "An Analysis of Fire Safety in Residential Buildings through Fire Statistics", Proceedings of the $6^{\text {th }}$ International Symposium on Fire Safety Science, Poitiers, France, 2000, p.219-230.

[4] Ono, R., Tomina, J.C. “Avaliação da segurança contra incêndio em edifícios de escritórios baseada no conhecimento, no nível de preocupação e na atuação dos usuários e dos responsáveis pela segurança (Fire safety evaluation of office buildings based on the occupants' level of concern and attitudes (IPT Technical Report \#49.054/2000) ), IPT/DEC/AISF, São Paulo, 2000.

[3] Ono, R. "The Social and Cultural Influences on the Human Behavior in Fires and in the Prevention in Japan - Final Report", The Japan Foundation Fellowship Program, Kyoto University Disaster Prevention Research Institute, Kyoto, 1999, 148p, 